\title{
The Pronunciation of The Hijaiyah Letters for Autistic Children at Extraordinary Islamic School Qothrunnada Yogyakarta
}

\author{
Nur Fauziah Alvin ${ }^{1}$, Ferawati ${ }^{2}$ \\ ${ }^{1,2}$ Program Studi Bahasa dan Sastra Arab Universitas Ahmad Dahlan, Indonesia
}

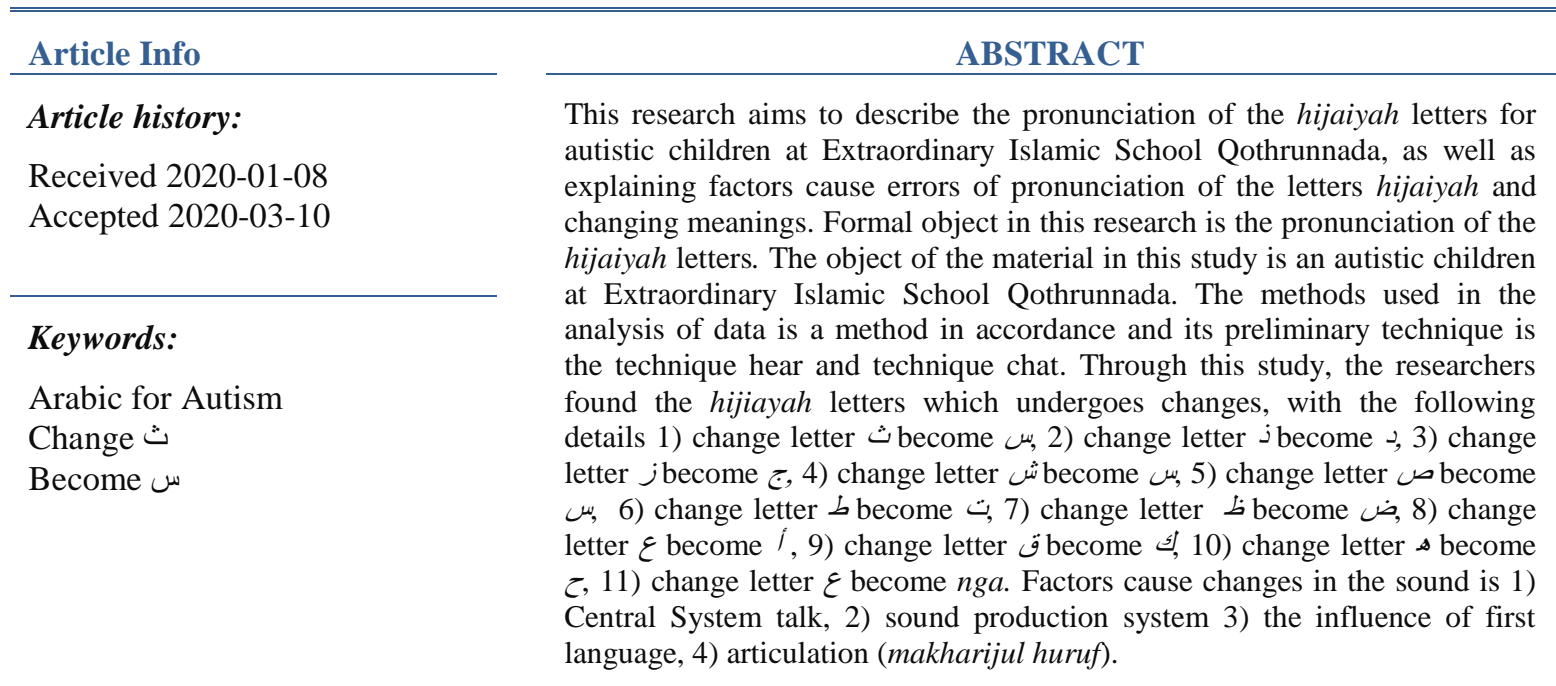

This is an open access article under the CC BY-SA license.

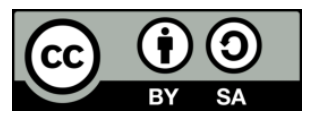

\section{Corresponding Author:}

Nur Fauziah Alvin,

Program studi Pendidikan Agama Islam,

Universitas Ahmad Dahlan,

Email: nur.alvin@uad.ac.id

\section{PENDAHULUAN}

Alat komunikasi paling efektif dan paling penting adalah bahasa. Bahasa merupakan alat komunikasi yang paling efektif untuk menyampaikan maksud atau ide tertentu kepada orang lain. Bahasa itu memiliki banyak aneka ragam, meskipun setiap bahasa memiliki kaidah atau pola yang sama, namun karena bahasa itu digunakan oleh penutur dengan latar belakang serta sosial yang berbeda-beda maka bahasa menjadi beraneka ragam dari segi fonologi, morfologi, sintaksis dan leksikon (Abdul, 2004: 14). Di Indonesia sendiri bahasa Arab merupakan bahasa asing, karena mayoritas penduduk Indonesia berbahasa Jawa, Sunda yang berbagai macam suku lainnya. Namun, bahasa Arab juga bukanlah hal asing karena sebagian atau mayoritas masyarakat Indonesia beragama Islam.

Ilmu fonologi yakni ilmu bunyi yang membahas tentang bunyi bahasa tertentu dengan mempertimbangkan fungsi dan makna yang dikandung oleh bunyi (Ahmad, TT: 5).

Bunyi adalah bagian dari bahasa, untuk menghasilkan bunyi yang baik maka diperlukan artikulasi, artikulasi adalah ruang saluran suara untuk menghasilkan bunyi bahasa (Harimukti, TT: 19). Bunyi 
bahasa Arab juga memerlukan artikulasi yang baik. Dalam bahasa Arab, huruf-huruf hijiayah tersusun atas 29 huruf, yakni :

$$
\text { أ ب ت ث ج ح خ د ذذر ز س ش ص ض ط ظع ع ف ق لك ل م ن و هـ }
$$

Pelafalan huruf-huruf hijaiyah haruslah dibunyikan sesuai artikulasi, karena apabila dalam pengucapan huruf-huruf hijaiyah tidak sesuai artikulasi maka bunyi yang diucapkan akan berubah dan maknanya pun akan berubah juga.

Kesalahan dalam pelafalan huruf hijiayah tidak hanya terjadi pada masyarakat umum saja, tetapi pada anak berkebutuhan khusus seperti anak autis juga masih sulit dalam mengucapkan huruf-huruf hijiayah yang sesuai artikulasi. Autis adalah merupakan ketidakmampuan seorang anak yang ditandai dengan gangguan indrawi, pola bermain, dan perilaku emosi. Ciri anak autis yang paling menonjol adalah kesendirian dan ciri lainnya mencakup masalah bahasa, komunikasi, dan perilaku stereotip atau terkadang tidak dapat berbicara atau bila terdapat keterampilan berbahasa (Jeffrey, TT: 146). Autisme juga bukanlah penyakit kejiwaan, tetapi gangguan yang terjadi pada otak, sehingga menyebabkan otak tidak dapat berfungsi selayaknya otak manusia normal (Aprilia, 2016). Hal yang menarik dalam penelitian ini adalah ketika penutur mengucapkan kata بَنْهَا [bana:ha] yang berarti membangun menjadi بَنَ [banaha] yakni berubahnya huruf $₫$ [ha] menjadi huruf $乙$ [ha] dan hilangnya huruf $I$ [?] . sehingga yang seharusnya memiliki makna atau arti menjadi tidak memiliki arti. Seperti kalimat ذَبَحَ [ðabaha] yang berarti menyembelih berubah menjadi دَبََّdabaha] dengan perubahan bunyi ذَّ menjadi bunyi د berubah pula artinya menjadi tidak ada arti. Contoh lainnya زَيَنَ [zajana] yang berarti menjadi baik berubah menjadi جَ [dzajana] dengan berubahnya bunyi j menjadi bunyi ج artinya berubah menjadi tidak ada arti. Berdasarkan uraian di atas, permasalahan pokok yang terdapat dalam penelitian ini adalah; 1. Bagaimanakah pelafalan huruf-huruf hijaiyah anak autis di SLBI Qothrunnada Yogyakarta; 2. Apa faktor penyebab perubahan dalam pelafalan huruf-huruf hijaiyah bagi anak autis?; 3. Bagaimana perubahan makna yang terjadi akibat perubahan bunyi huruf-huruf hijaiyah bagi anak autis?.

\section{METODE}

Penelitian ini menggunakan pendekatan metode padan, dan sumber data dalam penelitian ini didapat dari salah satu siswa SLBI Qothrunnada. Tahap lanjutan dari teknik simak yakni berupa teknik libat cakap. Maksud dari teknik libat cakap karena peneliti berpartisipasi langsung dalam pembicaraan dan menyimak pembicaraan, sehingga peneliti melakukan dialog secara langsung dengan penutur. Dalam penelitian ini, peneliti memperhatikan setiap huruf-huruf hijaiyah yang diucapkan oleh penutur. Peneliti melakukan penyimakan kemudian melakukan perekaman yang menjadi data penelitian serta memilah bunyi yang mengalami perubahan. Pada analisis data, metode yang digunakan adalah metode padan intralingual. Metode padan intralingual adalah metode yang menghubung-bandingkan unsur-unsur yang bersifat lingual, baik dalam suatu bahasa maupun dalam beberapa unsur bahasa yang berbeda. Pelaksanaan metode ini menggunakan teknik hubung banding membedakan (HBB). Berikut adalah gambaran yang lebih jelas mengenai langkah-langkah dalam penganalisisan data: a) Menentukan datadata yang akan dianalisis. b) Peneliti menganalisis data berdasarkan transkipsi fonetis berdasarkan IPA. Peneliti memilih menggunakan transkipsi fonetis IPA karena mampu menjelaskan transkipsi fonetik dalam bahasa Arab. Melalui analisis transkipsi tersebut, peneliti kemudian mengidentifikasi bentuk perubahan bunyi yang terjadi pada data. c) Menarik kesimpulan sebagai hasil dari analisis perubahan bunyi yang diucapkan anak autis. Hasil analisis dapat disajikan melalui dua cara, yaitu metode formal dan informal. Metode informal adalah perumusan hasil analisis data menggunakan kata-kata biasa dan terperinci, sedangkan metode formal adalah menggunakan tanda-tanda atau lambang dan terkesan ringkas. Kedua teknik tersebut digunakan untuk penyajian hasil analisis data agar penjelasan dari hasil analisis data menjadi lebih efektif. 


\section{HASIL DAN PEMBAHASAN}

Adapun hasil analisis terbagi menjadi dua ketegori, pertama huruf-huruf yang tidak mengalami perubahan bunyi dan yang kedua huruf-huruf yang mengalami perubahan bunyi. Huruf-huruf yang tidak أ,ب,

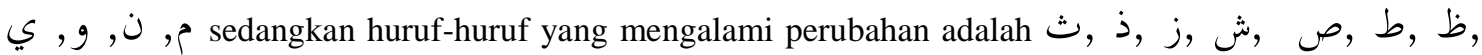
$\mathcal{\varepsilon}, \ddot{\Theta}, \infty$, dengan rincian sebagai berikut:

1. Huruf $ث[\theta]$ berubah menjadi س $[\mathrm{s}]$

Tabel 1

\begin{tabular}{|c|c|c|c|c|c|c|}
\hline $\mathrm{N}$ & Bun & $\mathrm{K}$ & Transkipsi & Diucap & Transkipsi & Perubahan \\
\hline o & yi & $\begin{array}{l}\text { at } \\
\text { a }\end{array}$ & Fonetis & kan & Fonetis & Bunyi \\
\hline 1 & $\begin{array}{l}\text { awa } \\
1\end{array}$ & تَنَرَ & [0abara] & سَبَرَ & [sabara] & {$[\theta]$ menjadi $[\mathrm{s}]$} \\
\hline 2 & $\begin{array}{l}\text { teng } \\
\text { ah }\end{array}$ & جَهَ جَّ & [dza日ama] & جَسَنَ & [dzasama] & {$[\theta]$ menjadi $[\mathrm{s}]$} \\
\hline 3 & $\begin{array}{l}\text { akhi } \\
\text { r }\end{array}$ & حَبْ & 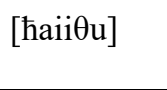 & حَيْسُ & [haiisu] & {$[\theta]$ menjadi $[\mathrm{s}]$} \\
\hline
\end{tabular}

2. Huruf $\dot{j}[$ ð] menjadi $د[\mathrm{~d}]$

\begin{tabular}{|c|c|c|c|c|c|c|}
\hline $\mathrm{N}$ & Bun & $\mathrm{K}$ & Transkipsi & Diucap & Transkipsi & Perubahan \\
\hline o & yi & $\begin{array}{l}\text { at } \\
\text { a }\end{array}$ & Fonetis & kan & Fonetis & Bunyi \\
\hline $\begin{array}{l}1 \\
.\end{array}$ & $\begin{array}{l}\text { awa } \\
\text { l }\end{array}$ & ذَبَ & [ðabaћa] & دَبَحَ & [dabaha] & $\begin{array}{l}{[ð] \text { menjadi }} \\
{[\mathrm{d}]}\end{array}$ \\
\hline 2 & $\begin{array}{l}\text { teng } \\
\text { ah }\end{array}$ & حَذَّ رَ & [haðara] & حَدَرَ ل & [hadara] & $\begin{array}{l}{[\partial] \text { menjadi }} \\
{[\mathrm{d}]}\end{array}$ \\
\hline $\begin{array}{l}3 \\
.\end{array}$ & $\begin{array}{l}\text { akhi } \\
\text { r }\end{array}$ & خَذَّالَا & [la?axaða] & لَاخَدَ & [la?axada] & $\begin{array}{l}{[ð] \text { menjadi }} \\
{[\mathrm{d}]}\end{array}$ \\
\hline
\end{tabular}

3. Huruf $j[z]$ menjadi $\underset{z}{[d z}]$

Tabel 3

\begin{tabular}{|c|c|c|c|c|c|c|}
\hline $\mathrm{N}$ & Bun & $\mathrm{K}$ & Transkipsi & Diucap & Transkipsi & Perubahan \\
\hline o & yi & $\begin{array}{l}\text { at } \\
\text { a }\end{array}$ & Fonetis & kan & Fonetis & Bunyi \\
\hline 1 & $\begin{array}{l}\text { awa } \\
1\end{array}$ & نَيَ & [zajana] & جَيَنَ & [dzajana] & $\begin{array}{l}\text { [za] menjadi } \\
{[\mathrm{d} 3]}\end{array}$ \\
\hline 2 & $\begin{array}{l}\text { teng } \\
\text { ah }\end{array}$ & لََزَ & [nazala] & نَجَلَ & [nadzala] & $\begin{array}{l}\text { [za] menjadi } \\
{[\mathrm{d} 3]}\end{array}$ \\
\hline 3 & $\begin{array}{l}\text { akhi } \\
\mathrm{r}\end{array}$ & زَرَ & [baraza] & بَرَجَ & [baradza] & $\begin{array}{l}\text { [za] menjadi } \\
{\left[\mathrm{d}_{3}\right]}\end{array}$ \\
\hline
\end{tabular}

4. Huruf ش $\left[\int\right]$ menjadi w $[\mathrm{s}]$

\begin{tabular}{|c|c|c|c|c|c|c|}
\hline $\mathrm{N}$ & Bun & $\mathrm{K}$ & Transkipsi & Diucap & Transkipsi & Perubahan \\
\hline o & yi & $\begin{array}{l}\text { at } \\
\text { a }\end{array}$ & Fonetis & kan & Fonetis & Bunyi \\
\hline $\begin{array}{l}1 \\
.\end{array}$ & $\begin{array}{l}\text { awa } \\
1\end{array}$ & شَنَ & [ fa Vala $]$ & سَغَلَ & [saYala] & $\begin{array}{l}{[\mathrm{fa}] \text { menjadi }} \\
{[\mathrm{sa}]}\end{array}$ \\
\hline 2 & $\begin{array}{l}\text { teng } \\
\text { ah }\end{array}$ & فَث & [kafafa] & كَسَفت & [kasafa] & $\begin{array}{l}{[\mathrm{fa}] \text { menjadi }} \\
{[\mathrm{sa}]}\end{array}$ \\
\hline 3 & $\begin{array}{l}\text { akhi } \\
\mathrm{r}\end{array}$ & فَرَ & {$[$ fara $\sqrt{a}]$} & فَرَسَ & [farasa] & $\begin{array}{l}{\left[\int \mathrm{a}\right] \text { menjadi }} \\
{[\mathrm{sa}]}\end{array}$ \\
\hline
\end{tabular}


5. Huruf ص[ $\left[\mathrm{s}^{\uparrow}\right]$ menjadi w $[\mathrm{s}]$

\begin{tabular}{|c|c|c|c|c|c|c|}
\hline $\begin{array}{l}\mathrm{N} \\
\mathrm{O} \\
.\end{array}$ & $\begin{array}{l}\text { Bun } \\
\text { yi }\end{array}$ & $\begin{array}{l}\mathrm{K} \\
\text { at } \\
\mathrm{a}\end{array}$ & $\begin{array}{l}\text { Transkipsi } \\
\text { Fonetis }\end{array}$ & $\begin{array}{l}\text { Diucap } \\
\text { kan }\end{array}$ & $\begin{array}{l}\text { Transkipsi } \\
\text { Fonetis }\end{array}$ & $\begin{array}{l}\text { Perubahan } \\
\text { Bunyi }\end{array}$ \\
\hline $\begin{array}{l}1 \\
.\end{array}$ & $\begin{array}{l}\text { awa } \\
1\end{array}$ & طَ & [s'ira: $\left.t_{n}^{\varphi^{\prime}} \mathrm{a}\right]$ & سِرَطَ & {$\left[\operatorname{sirat}_{n}^{\dagger} \mathrm{a}\right]$} & $\begin{array}{l}\left.\mathrm{s}^{\mathrm{\varsigma}}\right] \text { menjadi } \\
{[\mathrm{s}]} \\
\text { Diikuti dengan } \\
\text { vokal i ( })\end{array}$ \\
\hline $\begin{array}{l}2 \\
.\end{array}$ & $\begin{array}{l}\text { teng } \\
\text { ah }\end{array}$ & فِ & [Sa:s'ifa] & عَسِفت & [Sasifa] & $\begin{array}{l}{\left[\mathrm{s}^{\mathrm{c}}\right] \text { menjadi }} \\
{[\mathrm{s}]} \\
\text { Diikuti dengan } \\
\text { vokal i ( })\end{array}$ \\
\hline
\end{tabular}

6. Huruf $b\left[t_{n}^{\mathrm{s}}\right]$ menjadi $ت[\mathrm{t}]$

\begin{tabular}{|c|c|c|c|c|c|c|}
\hline $\begin{array}{l}\mathrm{N} \\
\mathrm{O} \\
.\end{array}$ & $\begin{array}{l}\text { Bun } \\
\text { yi }\end{array}$ & $\begin{array}{l}\mathrm{K} \\
\text { at } \\
\mathrm{a} \\
\end{array}$ & $\begin{array}{l}\text { Transkipsi } \\
\text { Fonetis }\end{array}$ & $\begin{array}{l}\text { Diucap } \\
\text { kan }\end{array}$ & $\begin{array}{l}\text { Transkipsi } \\
\text { Fonetis }\end{array}$ & $\begin{array}{l}\text { Perubahan } \\
\text { Bunyi }\end{array}$ \\
\hline 1 & $\begin{array}{l}\text { awa } \\
1\end{array}$ & اقَ طِبَ & [țiba:qa] & تِبَبَاقَ & [tiba:qa] & 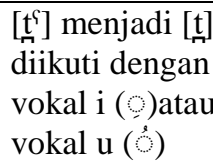 \\
\hline $\begin{array}{l}2 \\
.\end{array}$ & $\begin{array}{l}\text { teng } \\
\text { ah }\end{array}$ & شَ & [ $\left.\mathrm{a}: t_{n}^{\dagger} \mathrm{i} i \mathrm{i}\right]$ & سَتِّيُ & [satipi] & $\begin{array}{l}{\left[\mathrm{t}^{\varsigma}\right] \text { menjadi }[\mathrm{t}]} \\
\text { diikuti dengan } \\
\text { vokal i (o)atau } \\
\text { vokal u (\&) }\end{array}$ \\
\hline $\begin{array}{l}3 \\
.\end{array}$ & $\begin{array}{l}\text { akhi } \\
\mathrm{r}\end{array}$ & بَأُس & [ba:siț u] & بَبِتُ & [basitu] & $\begin{array}{l}{\left[\mathrm{t}^{\mathrm{q}}\right] \text { menjadi }[\mathrm{t}]} \\
\text { diikuti dengan } \\
\text { vokal i (o) } \\
\text { atau vokal u } \\
(\dot{8})\end{array}$ \\
\hline
\end{tabular}

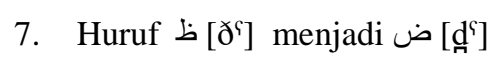

\begin{tabular}{|c|c|c|c|c|c|c|}
\hline $\mathrm{N}$ & Bun & $\mathrm{K}$ & Transkipsi & Diucap & Transkipsi & Perubahan \\
\hline $\begin{array}{l}\text { o } \\
.\end{array}$ & yi & $\begin{array}{l}\text { at } \\
\text { a }\end{array}$ & Fonetis & kan & Fonetis & Bunyi \\
\hline 1 & $\begin{array}{l}\text { awa } \\
1\end{array}$ & ظَ & [ð`alama] & ضَلَََْ & [d'alama] & $\begin{array}{l}{\left[\delta^{\varsigma}\right] \text { menjadi }} \\
{\left[\mathrm{d}^{\varsigma}\right]}\end{array}$ \\
\hline 2 & $\begin{array}{l}\text { teng } \\
\text { ah }\end{array}$ & نَظَ & [nað`afa] & نَضَفَتَ & [nadn'afa] & $\begin{array}{l}{\left[\partial^{\complement}\right] \text { menjadi }} \\
{\left[d^{\varsigma}\right]}\end{array}$ \\
\hline $\begin{array}{l}3 \\
.\end{array}$ & $\begin{array}{l}\text { akhi } \\
\mathrm{r}\end{array}$ & ظََ & [hafad`a] & حَفَضَ & [hafadn $\left.{ }^{\complement} \mathrm{a}\right]$ & $\begin{array}{l}{\left[\check{\partial}^{\varsigma}\right] \text { menjadi }} \\
{\left[d^{\varsigma}\right]}\end{array}$ \\
\hline
\end{tabular}

8. Huruf \& [?] menjadi I [ [ ]

\begin{tabular}{|c|c|c|c|c|c|c|}
\hline \multicolumn{7}{|c|}{ Tabel 8} \\
\hline $\mathrm{N}$ & Bun & $\mathrm{K}$ & Transkipsi & Diucap & Transkipsi & Perubahan \\
\hline o & yi & at & Fonetis & kan & Fonetis & Bunyi \\
\hline . & & $\mathrm{a}$ & & & & \\
\hline 1 & awa & عَقَّ & [Saqama] & أَفَمَ & [?aqama] & [S] menjadi [?] \\
\hline . & 1 & $\tilde{\rho}$ & & & & \\
\hline 2 & teng & فَعَ & [faSala] & فَالَّ & [farala] & [§] menjadi [?] \\
\hline . & ah & Ju & & & & \\
\hline 3 & akhi & كَنَ & [kataSa] & كَتًا & [kata?a] & [§] menjadi [?] \\
\hline . & $\mathrm{r}$ & $\varepsilon$ & & & & \\
\hline
\end{tabular}


9. Huruf $[\mathrm{q}]$ menjadi $\operatorname{sik}]$

Tabel 9

\begin{tabular}{|c|c|c|c|c|c|c|}
\hline $\mathrm{N}$ & Bun & $\mathrm{K}$ & Transkipsi & Diucap & Transkipsi & Perubahan \\
\hline $\begin{array}{l}\text { o } \\
\text {. }\end{array}$ & yi & $\begin{array}{l}\text { at } \\
\text { a }\end{array}$ & Fonetis & kan & Fonetis & Bunyi \\
\hline $\begin{array}{l}1 \\
.\end{array}$ & $\begin{array}{l}\text { teng } \\
\text { ah }\end{array}$ & تَنْوِ & [taqwi:mi] & تَكَكْوِنْ & [takwi:m] & $\begin{array}{l}\text { [q] menjadi } \\
{[\mathrm{k}] \text { apabila }} \\
\text { bunyi [q] } \\
\text { diikuti harakat } \\
\text { sukun (̊) }\end{array}$ \\
\hline
\end{tabular}

10. Huruf $ح[\hbar]$ menjadi $\diamond[\mathrm{h}]$

\begin{tabular}{|c|c|c|c|c|c|c|}
\hline $\mathrm{N}$ & Bun & $\mathrm{K}$ & Transkipsi & Diucap & Transkipsi & Perubahan \\
\hline $\begin{array}{l}0 \\
.\end{array}$ & yi & $\begin{array}{l}\text { at } \\
\text { a }\end{array}$ & Fonetis & kan & Fonetis & Bunyi \\
\hline 1 & $\begin{array}{l}\text { awa } \\
1\end{array}$ & حَ' حَ' & [hakama] & هَكَحَ & [hakama] & $\begin{array}{l}\text { [h] menjadi } \\
{[\mathrm{h}]}\end{array}$ \\
\hline 2 & $\begin{array}{l}\text { akhi } \\
\mathrm{r}\end{array}$ & قَبَحَح & [qabaha] & فَبَبَ & [qabaha] & $\begin{array}{l}{[\hbar] \text { menjadi }} \\
{[\mathrm{h}]}\end{array}$ \\
\hline
\end{tabular}

11. Huruf \& [؟] menjadi nga

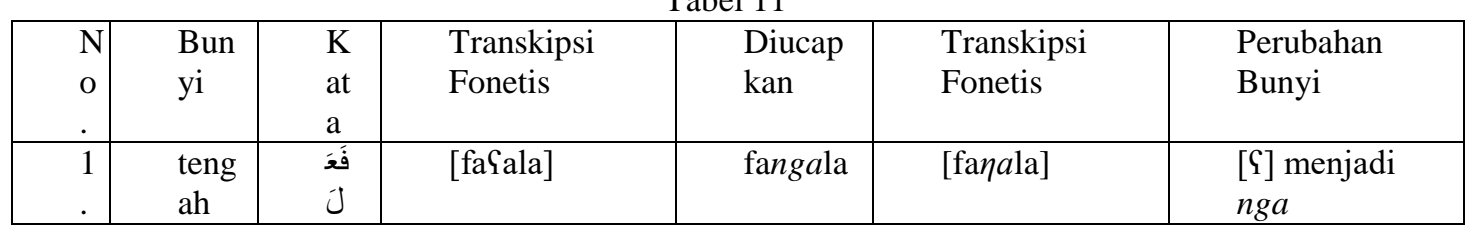

Beberapa faktor penyebab perubahan bunyi huruf-huruf hijaiyah adalah :

1) Sistem Pusat bicara dan bahasa

Gangguan atau cedera otak merupakan akibat terjadinya gangguan berbahasa dan berbicara. Informan lebih cenderung mengalami afasia sensorik. Afasia sensorik disebabkan adanya kerusakan didaerah Wernicke, tepatnya didaerah leksikortikal. Kerusakan didaerah ini menyebabkan gangguan pemahaman audiotoris dan pemahaman visual. informan kurang mampu memahami bahasa lisan dan bahasa tulis, meskipun masih mampu berbahasa lisan yang tidak bermakna dan sulit dipahami.

2) Sistem produksi bahasa Selain bersuara sengau penutur juga mangalami gangguan komunikasi verbal seperti membeo atau ekolalia. Ekolalia adalah pengulangan dari apa yang dikatakan oleh orang lain. Anak dengan ekolalia akan meniru perkataan yang mereka dengar dari orang lain dalam kehidupan

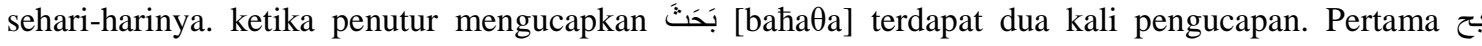
[baha], kedua, بحس [bahasa]. Hal ini terjadi dikarenakan penutur mengikuti apa yang guru ajarkan, sehingga terjadi perstiwa ekolalia. Selain terjadi ekolalia, terlihat juga adanya perubahan bunyi antara bunyi ثyang berubah menjadi bunyi w hal ini disebabkan karena letak artikulasi berdekatan.

3) Pengaruh bahasa pertama

Perubahan pada huruf-huruf hijaiyah terjadi karena adanya pengaruh bahasa pertama, yakni dialek jawa. Pelafalan informan dipengaruhi dialek yang digunakan oleh keluarga dan lingkungannya. Dalam penelitian ini terdapat perubahan bunyi yang dipengaruhi oleh dialek jawa adalah: $\varepsilon$ yang berubahn menjadi nga.

4) Letak Artikulasi (makharijul huruf)

Kesalahan dalam artikulasi dapat disebabkan karena letak artikulasi yang sama, berdekatan, berjauhan dan pengaruh bahasa lain. Berikut ini ada beberapa artikulasi yang menyebabkan terjadinya perubahan

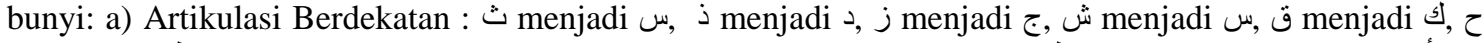

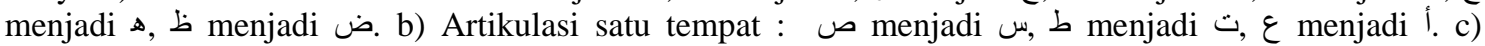
Artikulasi yang tidak terdapat dalam hijaiyah : $\varepsilon$ menjadi nga. Kesalahan dalam artikulasi dapat menimbulkan perbedaan arti pada suatu kata. Pada tuturan anak autis di SLBI Qothrunnada, peneliti menemukan beberapa kata yang seharusnya memiliki arti berubah menjadi kata yang tidak memiliki arti dikarenaka perubahan artikulasi.

Tabel 12 


\begin{tabular}{|c|c|c|c|c|}
\hline No. & $\begin{array}{l}\text { Kosa kata } \\
\text { bahasa Arab }\end{array}$ & Makna & $\begin{array}{l}\text { Perubahan } \\
\text { pengucapan } \\
\text { kata }\end{array}$ & $\begin{array}{l}\text { Perubahan } \\
\text { makna }\end{array}$ \\
\hline 1. & تَبَرَرَ & binasa & سَبَرَ & mengukur \\
\hline 2. & جَنََّ & bertengger & جَسََْ & $\begin{array}{l}\text { tidak } \\
\text { memiliki } \\
\text { makna }\end{array}$ \\
\hline 3. & حَبْثُ & dimana & حَبْسُ & $\begin{array}{l}\text { tidak } \\
\text { memiliki } \\
\text { makna }\end{array}$ \\
\hline 4. & ذَبَحَ & memotong & دَبَحَ & menghias \\
\hline 5. & حَذَرَ & $\begin{array}{l}\text { berhati- } \\
\text { hati/waspada }\end{array}$ & حَدَرَ & Turun \\
\hline 6. & 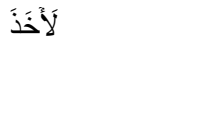 & jangan diambil & لَاََخَد & $\begin{array}{l}\text { tidak } \\
\text { memiliki } \\
\text { makna }\end{array}$ \\
\hline 7. & زَيَنَ & menghias & جَيَنَ & $\begin{array}{l}\text { tidak } \\
\text { memiliki } \\
\text { makna }\end{array}$ \\
\hline 8. & نَزَزَلَ & turun & نَجَلَ & menendang \\
\hline 9. & بَرَزَ & $\begin{array}{l}\text { muncul atau } \\
\text { timbul }\end{array}$ & بَرَجَ & Mewah \\
\hline 10. & شَغَلَل & sibuk & سَغَلَ & $\begin{array}{l}\text { tidak } \\
\text { memiliki } \\
\text { makna }\end{array}$ \\
\hline 11. & كَثَفَ & membuka & كَسَفَ & menutupi \\
\hline 12. & فَرَشَ & membentangkan & فَرَسَ & memburu \\
\hline 13. & صِرَاطًَ & jalan & سِرَطَ & $\begin{array}{l}\text { tidak } \\
\text { memiliki } \\
\text { makna }\end{array}$ \\
\hline 14. & عَاصِفت & badai & عَسِفت & $\begin{array}{l}\text { tidak } \\
\text { memiliki } \\
\text { makna }\end{array}$ \\
\hline 15. & طِبَاقَ & berlapis-lapis & تِتَبَقَ & $\begin{array}{l}\text { tidak } \\
\text { memiliki } \\
\text { makna }\end{array}$ \\
\hline 16. & شَاطِيُ & tepi laut & سَتِّيُ & $\begin{array}{l}\text { tidak } \\
\text { memiliki } \\
\text { makna }\end{array}$ \\
\hline 17. & بَاسبطُ & mengembangkan & بَسبتُ & $\begin{array}{l}\text { tidak } \\
\text { memiliki } \\
\text { makna }\end{array}$ \\
\hline 18. & ظظلَحَ & meletakkan & ضَلَََ & $\begin{array}{l}\text { tidak } \\
\text { memiliki } \\
\text { makna }\end{array}$ \\
\hline 19. & نَظَفت & membersihkan & نَضَتَفت & menghabiskan \\
\hline 20. & حَفَظً & menjaga & حَفَضَ & $\begin{array}{l}\text { tidak } \\
\text { memiliki } \\
\text { makna }\end{array}$ \\
\hline 21. & عَقَمَ & $\begin{array}{l}\text { mandul/ tidak } \\
\text { subur }\end{array}$ & أَفَََْ & $\begin{array}{l}\text { tidak } \\
\text { memiliki } \\
\text { makna }\end{array}$ \\
\hline 22. & فَعَلَ & mengerjakan & فَالَ & $\begin{array}{l}\text { tidak } \\
\text { memiliki } \\
\text { makna }\end{array}$ \\
\hline 23. & كَتَعَ & pergi & كَتَّأ & $\begin{array}{l}\text { tidak } \\
\text { memiliki } \\
\text { makna }\end{array}$ \\
\hline 24. & تَقِْْيْمِ & bentuk & تَكْوِيْج & tidak \\
\hline
\end{tabular}




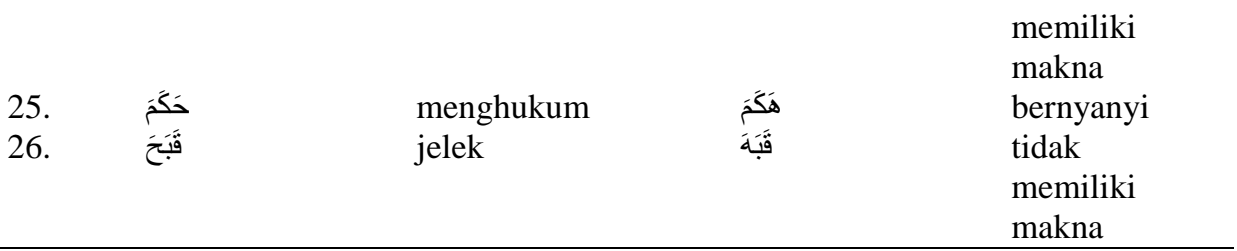

\section{KESIMPULAN}

Penelitian ini membahas tentang cara pengucapan huruf-huuf hijaiyah bagi anak autis di SLBI Qothrunnada Yogyakarta. Berdasarkan pembahasan sebelumnya peneliti menyimpulakan bahwa pelafalan yang dilakukan anak autis di SLBI Qothrunnada terdapat kesulitan dalam pelafalan huruf

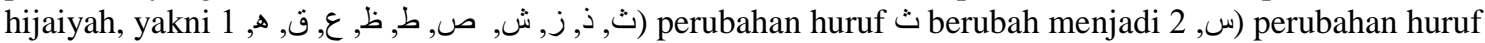

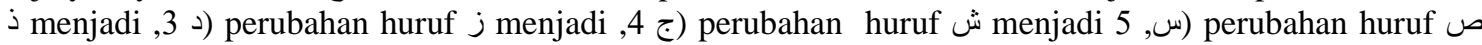

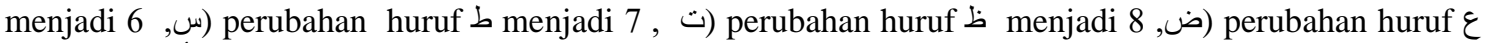
menjadi 9 , (أ) perubahan huruf menjadi 10, (ك) perubahan huruf menjadi nga. Faktor-faktor penyebab dari kesalahan dalam pelafalan huruf-huruf hijiayah yang dialami anak autis di SLBI Qothrunnada adalah karena faktor 1) sistem pusat bicara dan bahasa, 2) sistem produksi suara, 3) pengaruh bahasa pertama atau bahasa ibu, dan 3) Artikulasi (Makharijul Huruf)

Perubahan bunyi juga mempengaruhi makna suatu kata, dalam penelitian ini terdapat 9 kata yang memiliki perubahan arti atau makna dan 17 kata yang tidak memiliki arti atau makna. Berdasarkan hasil penelitian yang telah dilakukan, maka peneliti mengajukan beberapa sarankepada pembaca dan pembelajar bahasa Arab: 1. Peniliti berharap adanya penelitian-penelitian lainnya mengenai pengucapan pada anak-anak ABK yang lain, dikarenakan masih banyaknya hal yang perlu diteliti dan dikaji. 2. Hasil penelitian ini diharapkan dapat dijadikan sebegai referensi dalam memhami pelefalan pada anak-anak ABK lainnya. 3. Bagi mahasiswa bahasa Arab, hendaknya mengerti dan lebih memahami tentang pelafalan bahasa Arab. 4. Bagi tenaga pengajar, diharapkan penelitian in dapat dijasikan refereni sebagi bahan binaan mengaji dalam memperbaiki pelafalan. Selain ini diharapkan kepada seluruh tenaga pengajar mengetahui dan melafalkan makhorijul huruf dengan baik dan benar, agar tidak menjadi suatu kebiasaan dan kesalahan dimasa yang akan datang.

\section{REFERENSI}

Al-Mujahid, Thoha Husein dan Atho'illah Fathoni Al-Khalil. 2016, Kamus Al-Wafi Arab-Indonesia Jakarta: Gema Insani

Arifuddin. 2013. Neuropsikolinguistik, Jakarta: Rajawali Press

Bisri, Adib dan Munawwir A. Fatah. 2002, Kamus Al-Bisri, Surabaya : Pustaka Progresif

Chaer, Abdul. 2009. Fonologi Bahasa Indonesia Jakarta: PT Rineka Cipta dan Leonie Agustina. 2004. Sosiolinguistik Perkenalan Awal, Jakarta: PT Rineka Cipta 2000 Buku Iqra Jilid 3, Yogyakarta, Balai Litbang LPTQ Nasional 2009. Pengantar Semantik Bahasa Indonesia Jakarta: PT Rineka Cipta

Fatmasari, Fajria. 2011, Gangguan Berbahasa Pada Anak, Tesis, Universitas Gadjah Mada.

Harry, Fauzan. 2015, Penyimpangan Bahasa Pada Anak Autis, Skripsi, Universitas Gadjah Mada.

Humam, As'ad. 2000. Buku Iqra Jilid2, Yogyakarta, Balai Litbang LPTQ Nasional

Ifka, Ifani. 2013, Kesulitan Pelafalan Huruf-Huruf Hijaiyah Yang Tidak Terdapat Di Huruf Indonesia pada Masyarakat Saradan Wonogiri, Skripsi, Universitas Negeri Semarang.

Jauhar, Nasaruddin idris. 2015, Fonologi Bahasa Arab untuk Penutur Bahasa Indonesia, Sidoarjo: Lisan Arab

Kridalaksana, Harimukti. 2008, Kamus Linguistik edisi 4, Jakarta: Gramedia Pustaka Utama.

Ma'hun Ali dan Zainal Abidin Munawwir, 2002, Kamus Al-Munawwir Arab-Indonesia, Surabaya: Pustaka Progresif

Muslich, Masnur, Fonologi Bahasa Indonesia Tinjauan Deskriptif Sistem Bunyi Bahasa Indonesia, (Jakarta: Bumi Aksara)

Nevid, Jeffrey S. 2003, Psikologi Abnormal . Edisi ke lima. Jilid II. Jakarta: Erlangga, 
Rusydi, Aiman. 2015, Panduan ilmu Tajwid Bergambar. Solo: Zam-zam

Safitri Ramdhani, Aprilia, Koran Republika (Selasa, 12 April 2016)

Sayuti, Ahmad. 2012, Bunyi Bahasa, Jakarta: AMZAH.

Soepomo, 2002, Dasar-Dasar Linguistik, Yogyakarta: Tiara wacana

Sudaryanto. 2015, Metode dan Aneka Teknik Analisis Bahasa, Yogyakarta: Sanata Dharma University Press Tarigan, Henry Guntur. 2011, Pengajaran Kosa Kata, Bandung: Angkasa

Yuwono, Joko. 2009, Memahami Anak Autistik Kajian Teoritik dan Empirik, Bandung: Alfabeta

Http://Berkomunikasi.com diakses pada tanggal 26 Maret 2017

Http://Spechclinic.wordpress.com diakses pada tanggal 03 November 2016

Http://www.anakku.net diakses pada tanggal16 september 2016

http://www.internationalphoneticalphabet.org/ipa-sounds/ipa-chart-with-sounds/ diakses pada tanggal 04 Februari 2016

http://yadinayogyakarta.blogspot.co.id/ diakses pada tanggal 14 November 2016

https://apraksia.com diakses pada tanggal 05 Mei 2017

https://id.wikipedia.org/wiki/Alfabet_Fonetis_Internasional dikases pada tanggal 12 April 2017 